\title{
Japanese concept of Kogei in the period between the First World War and the Second World War
}

\author{
Yoshinori Amagai / Akita University of Art / Akita / Japan
}

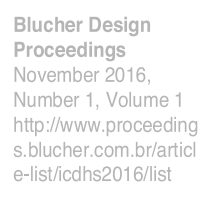

\begin{abstract}
In Japan in the period between the First World War and the Second World War, Rokuzo Yasuda defined Kogei in general as applied art industry, while there were three major movements of Kogei: Bijutsu Kogei, Sangyo Kogei, and Mingei. Sangyo Kogei and Mingei were considered to be counter-movements to Bijutsu Kogei. Sangyo Kogei and Bijutsu Kogei, however, were translated by using the same English expression, 'industrial art', and the English expression 'folk craft' was applied to Mingei. In this paper, focusing on the arguments about Kogei at the time, I suggest that the Japanese concept of Kogei meant not only crafts but also industrial design, and its fundamental aim was to beautify our daily life by unifying beauty and utility. Yasuda's definition and others' arguments about Japanese Kogei provided important foundations for the development of the modern design movement, especially industrial design, in postwar Japan.
\end{abstract}

\section{Keywords}

Japanese Kogei, crafts, industrial art, industrial design

\section{Introduction}

The Japanese word Kogei, as well as the Japanese word Bijutsu, has rich layers of meaning. It is very difficult to translate the Japanese word Kogei and to interpret its old meaning using modern language. Some experts define Kogei as 'crafts' or 'arts and crafts', some as 'applied art', while others as 'industrial art' or 'industrial design'. In his paper presented in 1937, Rokuzo Yasuda (1874-1942), president of the Tokyo Koto Kogei Gakko (Tokyo Higher School of Arts and Technology), explained that the Japanese word Kogei stood for 'artistic industry', or 'applied art', and at the same time he used the expression 'applied art industry' to mean Kogei. Today, Yasuda's definition of Kogei as 'artistic industry' or 'applied art industry' sounds somewhat strange. His definition of Kogei in general, however, is one of various hefty arguments about the Japanese concept of Kogei. According to Shinji Koike (1901-1981), a representative Japanese design critic and educator in the Showa era, there were three major movements of Kogei, i.e., Bijutsu Kogei, Sangyo Kogei, and Mingei, in the period between the First World War and the Second World War.

This paper considers arguments regarding Kogei including its education, and I propose that the Japanese concept of Kogei at the time meant not only craft but also industrial design, and that its basic purpose was to embellish our everyday lives by uniting beauty and utility. Yasuda's definition and other discussions of Japanese Kogei have contributed significantly to the development of the modern design movement, particularly industrial design, in postwar Japan.

\section{Yasuda's definition of Kogei as applied art industry}

In Tokyo in August 1937, an international conference entitled the Seventh Biennial Conference of the World Federation of Education Association was held. In a section of the conference entitled 'Educational Crafts Section', Rokuzo Yasuda, president of the Tokyo Koto Kogei Gakko, read an English paper entitled 'Applied Art Industry in Japan' to give an outline of Japanese Kogei to foreigners. Yasuda's paper shows us the general meaning of Japanese Kogei at the time.

The Japanese term Kogei, Yasuda says, may be rendered in English as 'artistic industry', and 
stands for the term 'applied art' commonly used in the West. After having stated that the interpretation of 'artistic industry', or Kogei, necessarily differs from person to person and that perfect agreement as to its definition may be impossible, Yasuda presents his definition of 'artistic industry' based on common sense. 'Artistic industry', Yasuda explains, is concerned with products for daily life which should serve the varied necessities of mankind and the desire for beauty. Today, the English expression 'applied art industry', which consists of the two terms 'applied art' and 'artistic industry' to mean Kogei, feels a little peculiar. The expression, however, reflects the historical and educational condition of Kogei in the Japan of the 1930s.

According to Yasuda, after the Meiji Restoration (1868), Japan learned many things from the West, especially in scientific industry, which had been non-existent in Japan, and about mechanical and scientific methods as applicable to artistic industry. Japanese people, Yasuda says, believe that it is the mission of their nation to harmonize the inherent culture of the East with the modern culture of Europe and America, and thus produce a new culture. To realize this mission, Japan established applied art education from primary to higher grades. The fundamental training for applied art in primary school is drawing and manual work. The courses of study at middleschool grade in art and craft schools (Kogei Gakko) or industrial schools (Kogyo Gakko) consist of metal work (Kinko), ceramics (Yogyo), lacquer work (Shikko), weaving and dyeing (Senshoku), architecture (Kenchiku), design or decoration (Zuan), and so on. Many graduates of these schools, Yasuda points out, go out into the world to earn their living, and a few of them enter institutions of higher grade, such as the Tokyo Koto Kogei Gakko (Tokyo Higher School of Arts and Technology) founded in 1921 and the Kyoto Koto Kogei Gakko (Kyoto Higher Technical School) founded in 1902. The courses of study in these higher institutions at the time were technological design (Kogei Zuan), technological sculpture (Kogei Chokoku), minute machinery (Seimitsu Kikai), metal technology (Kinzoku Kogei), wood technology (Mokuzai Kogei), technical printing (Insatsu Kogei), photography (Shashin), technological weaving (Shikisen), technological ceramics (Yogyo), and architecture (Kenchiku).

Kogei defined by Yasuda as applied art industry could have broadened meanings from handicrafts to industrial machine-made products. In this meaning, Yasuda points out that the Japanese government should promote and encourage applied art industry in terms of foreign and domestic trade as social and industrial policy. Yasuda explains that the reason that this should be the case is that, in this industry, hand-made articles are much more highly appreciated than machine-made items. In addition, Yasuda stresses that there is hardly any commodity which does not require some manual work though the greater part may be machine-made.

On the other hand, in the same section of the conference, Toyochika Takamura (1890-1972), a professor of the Tokyo Bijutsu Gakko (Imperial Academy of Fine Arts, Tokyo), gave a definition of Bijutsu Kogei as industrial art with specific meanings.

\section{Takamura's definition of Bijutsu Kogei as industrial art}

Takamura begins his English paper entitled 'Basic Education of Industrial Art' with the following sentence.

First of all, it must be understood that in this article the word 'industrial art' is used to include only such manual work as may be regarded as of high artistic merit.

The Japanese proceedings of the conference show us that Takamura adopted the English expression 'industrial art' for the Japanese expression Bijutsu Kogei. Thus, the above sentence is a plain definition of Bijutsu Kogei. In his paper, Takamura solely treats the basic education in Bijutsu Kogei provided by the Tokyo Bijutsu Gakko because the academy founded in 1890 was considered to be representative of the educational facilities for industrial art in Japan at the time.

According to Takamura, a professor of metal work at the Tokyo Bijutsu Gakko, the student is given a preliminary education in the general idea of Bijutsu Kogei through lectures and training in the preparatory course of one year. Thus, the basic education, which the academy adopted in 1933, gives no practical training whatever in technical skill in any one branch of industrial art but is devoted to training in modelling (Sozo), charcoal drawing (Mokutan-ga), designing (Zuan), and Japanese painting (Nihon-ga).

Modelling and charcoal drawing, Takamura notes, are considered ideal arts for grasping the fundamentals of the three dimensions, and designing is concerned only with so-called abstract designing (JunsuiZuan), but not with its applied art. Training in Japanese painting is essential in education in industrial art. Takamura emphasizes that without sufficient dexterity in brush work it is very difficult to master the peculiar handicrafts of Japan such as metal carving and lacquer work. According to Takamura, in the course of Japanese painting, the student is to develop the faculty of grasping the true form of an object by delineating natural objects from life, and is encouraged to cultivate facility in manipulation of the brush (Unpitsu) by copying (Rinmo) old outline drawings (Hakubyo-ga). 
Lectures, Takamura says, supplement the training in order to give the student a general idea of what industrial art is. The subjects are the history of Oriental art, the history of Occidental art, principles of designing, and Oriental literature. Oriental literature is offered for the following five reasons: first, to exalt the national spirit; second, to explain the content and history of Japanese culture and how it came to be what it is; third, to show how closely industrial art is related to human life; fourth, to demonstrate the process through which Japanese culture has encouraged the development of peculiarly Japanese industrial art; and fifth, to promote, through studying the culture of our forefathers, understanding of present conditions and to outline the future course of our own culture.

Takamura's explanations of training and lectures in the basic education of the Tokyo Bijutsu Gakko show us that the peculiarity and artistic merits of Japanese Bijutsu Kogei, mainly metal work and lacquer work, are characterized principally by manipulation of the brush, which is cultivated by copying traditional outline drawings, and the content and history of Japanese culture, which Oriental literature reveal. Takamura, however, scarcely refers to the practical merits or utility of Bijutsu Kogei as industrial art in his paper. The Japan of the 1930s, focusing on the importance of manual work, Sangyo Kogei, and Mingei, which nobody mentioned in the conference, struggled to realize Kogei as a unity of beauty and utility in daily life.

\section{Sangyo Kogei and Mingei as counter-movements to Bijutsu Kogei}

According to Eiichi Izuhara (1929-2008), a representative Japanese design historian, Sangyo Kogei and Mingei starting in the early Showa era are considered to be counter-movements to Bijutsu Kogei, especially its academism. The Japanese term Sangyo Kogei, however, was applied to the English term 'industrial art', which was used to mean Bijutsu Kogei at the time. The expression 'industrial art' did not indicate the difference between Sangyo Kogei and Bijutsu Kogei.

In 1928, the Ministry of Commerce and Industry (Sho Ko Sho) established the Kogei Shidosho (Industrial Arts Research Institute) for the purpose of reviewing the traditional techniques of indigenous local handicrafts. Its aim was not only to promote export but also to utilize the surplus labor of the greatly depressed farm villages in the northeastern areas of Japan by industrializing traditional and local handicrafts, which were called Sangyo Kogei, in a scientific way. In his articles published in 1932, Kitaro Kunii (1883-1867), first president of the Kogei Shidosho, defined Sangyo Kogei as indigenous industrial products including both hand- and machine-made objects for daily use, which are beautified by unifying art and science, in other words, by harmonizing utility and beauty.

In Tokyo in 1936, Soetsu (Muneyoshi) Yanagi (1889-1961) established the Nihon Mingei-kan (Japan Folk Crafts Museum) to give a permanent home to works of indigenous local handicrafts, which Yanagi named Mingei. According to Yanagi, Mingei (folk craft or folk arts), an abbreviation of Minshuteki Kogei (folk handicraft), means various objects made by hand for everyday life. In contrast to Bijutsu Kogei, its main purpose is usability (Yo). 'Usability equals beauty' (Yo-soku-BI) in Mingei philosophy, in which Yanagi played a leading part from 1926 when he and his friends announced the prospectus of the foundation of a museum for folk craft.

In a statement published in 1932, Kunii evaluated the activities of the Mingei movement encouraging local production to realize reliable utility and natural beauty in their products for daily use, and asserted that Mingei and Sangyo Kogei faced the same direction toward new popular industrial art based on utility. In addition, Kunii considered that products led by the Mingei movement could be suited for export, and he advised leaders of the Mingei movement to introduce modern science carefully into the production process of handicrafts. But leading persons of the Mingei movement, Izuhara points out, criticized Sangyo Kogei for industrializing and mechanizing indigenous local handicrafts. For example, in his memoires published in 1962, Kageo Muraoka (1901-?), Yanagi's colleague, emphasized the idea that industrialization and mechanization led by the Kogei Shidosho were harmful to the wholesome development of local handicrafts, because the Mingei movement wanted not only to preserve indigenous local handicrafts but also to protect them from excessive industrialization and mechanization contaminated by capitalistic commercialism. Kunii's idea of Sangyo Kogei to promote the production process of Japanese handicrafts by applying scientific technology and to beautify industrial machine-made products by applying Japanese indigenous handicrafts may have been inappropriate for Mingei, even for Kikai Kogei which Yanagi had excluded from Mingei.

In his book entitled Kogei no Michi published in 1928, Yanagi considers both hand-made products called Kyodanteki Kogei (guild crafts), such as the best works being done under the Medieval guild system, and machine-made products called Kikai Kogei (industrial crafts), such as aluminum saucepans, as Mingei (folk crafts), because their main purpose is usability in everyday life. Yanagi, however, emphasizes the importance of handicrafts 
because of the poverty of material and beauty in most industrial machine-made goods (Kikai Kogei). Thus, in his book entitled Kogei Bunka published in 1937, Yanagi clearly excludes Kikai Kogei from Mingei, and points out that machine-made products should be beautified not by applying and imitating skilled handicrafts, but by designing a simple and straightforward form based on its own function. Machines, Yanagi says, should be elevated to be able to produce beautiful things for our everyday life, and a designer, whose intuition can perceive the proper beauty in a machine, is required for industrial machine-made products.

At that time, from an educational point of view, Yasuda, as well as Yanagi, stated that it was necessary not only to study the aesthetic problem of machines and machine-made products systematically, but also to train appropriate designers for machines and industrial machine-made products from battleships to commodities, such as gramophones, radio sets, cameras, clocks and wrist watches, gas fittings, electric heaters, electric fans, printers, film projectors, automobiles, electric trains, and so on. In order to meet these needs, Kogei in general should transit from traditional crafts to modern industrial and mechanical techniques. The transition, however, was nipped in the bud by the wartime governance established in 1943.

\section{Conclusion: From crafts to industrial design}

In 1949, when Japan, as one of the defeated Axis nations, was occupied under the Allied Forces, Shinji Koike published an article entitled 'Kogei kara Kogyoteki Sekkei he' (From crafts to industrial design). In this article, Koike criticizes Sangyo Kogei and Bijutsu Kogei for keeping feudal crafts unchanged, persisting in a traditional lifestyle, and forcing pre-modern tastes upon others, and he asserts that, in Japan after the Second World War, there was no serious relationship between the people's modern everyday life and Kogei as special protected crafts. Kogei in prewar Japan, Koike says, could not be considered as an integral element of various living facilities for our material environments. Thus, in postwar Japan, old concepts of Kogei, such as Bijutsu Kogei and Sangyo Kogei, should be wiped away, and new concepts of Kogei in general should be called Kogyo Sekkei (industrial design) or Indasutoriaru Dezain, which is an adoption of the English word 'industrial design' in syllabic translation, in order to humanize industrial technology on a large scale through cooperative relationships between designers and engineers.

By 1950, interest in industrial design prevailed in Japan, and many industrial products made in Japan, such as automobiles, auto-bikes, electronic fans, and cameras, appeared in the market and for export. This trend stimulated Japanese designers to establish the Nihon Indasutoriaru-Dezaina Kyokai (JIDA, Japan Industrial Designer Association) in 1952. It was in the postwar period that Kogei transited from crafts to industrial design, for which arguments about the Japanese concept of Kogei in the period between the First World War and the Second World War provided the basics.

\section{References}

Abe, K. (1960) Japanese Design in Progress, Tokyo: Japan Export Trade Promotion Agency. Hiesinger, K. B. and Fischer, F. (ed.) (1995) Japanese Design: A Survey Since 1950, New York: Harry N. Abrams, Incorporated.

Izuhara, E. (1989) Nihon no Dezain Undo: Indasutoriaru Dezain no Keihu, Tokyo: Perikansha.

Kikuchi, Y. (2004) Japanese Modernisation and Mingei Theory: Cultural Nationalism and Oriental Orientalism, London and New York: RoutledgeCurzon.

Koike, S. (1943) Hambi Keikaku, Tokyo: Atoriesha.

Koike, S. (1949) 'Kogei kara Kogyo Sekkei he', Kenchiku Zasshi, vol.64, no.755, pp.8-16.

Kunii, K. (1932) 'Jigen', Kogei Nyusu, vol.1, no.1, pp.2-3.

Kunii, K. (1932) 'Yushutsu Kogeihin Tenjikai Shuppimbutsu ni tsuite', Kogei Nyusu, vol.1, no.2, pp.2-4.

Kunii, K. (1932) 'Hompo Kogyo no Kogeiteki Shinten o Nozomu', Kogei Nyusu, vol.1, no.3, pp.1-2.

Kunii, K. (1932) 'Hompo Kogyo no Kogeiteki Shinten o Nozomu (Shozen)', Kogei Nyusu, vol.1, no.4, pp.1-2. Muraoka, K. (1962) 'Nihon no Mingei Undo', Dezain, no.29, pp.36-38.

Takamura, T. (1938) 'Basic Education in Industrial Art', in Proceedings of the Seventh Biennial Conference of the World Federation of Education Associations, Volume IV, Tokyo: The World Conference Committee of the Japanese Education Association.

Takamura, T. (1939) 'Kogei no Kiso Kyoiku ni tsuite', in Dai Nanakai Sekai Kyoiku Kaigi Rombunshu Dai Nikan, Tokyo: Teikoku Kyoikuki.

Tonomura K. (1992) Nature of Folk Craft: Aims of the Folk Craft Museum, Kurashiki: Kurashiki Museum of 
Folk Craft.

Yanagi, S. (1981) Yanagi Soetsu Zenshu, 22 vols, Tokyo: Chikuma Shobo.

Yanagi, S. (1989) The Unknown Craftsman: A Japanese Insight into Beauty, Revised edition, Tokyo and New York: Kodansha International.

Yasuda, R. (1936) 'Kikai no Biteki Kenkyu no Hitsuyo', Kikai Gakkai Shi, vol.39, no. 230, pp.309-310.

Yasuda, R. (1938) 'Applied Art Industry in Japan', in Proceedings of the Seventh Biennial Conference of the World Federation of Education Associations, Volume IV, Tokyo: The World Conference Committee of the Japanese Education Association.

Yasuda, R. (1939) 'Nihon no Kogei', in Dai Nanakai Sekai Kyoiku Kaigi Rombunshu Dai Nikan, Tokyo: Teikoku Kyoikukai.

\section{Biographical note}

AMAGAI Yoshinori, PhD (University of Tsukuba), is Professor in Art and Design History at Akita University of Art, Japan. He has published his article on pioneers of Japanese design education in the Meiji era in the Journal of the Asian Conference of Design History and Theory. 